\title{
Study of Moisture Budget of Meteorological Droughts over Indian Region
}

\author{
P. Suneetha ${ }^{1}$, Zedek, M. D. ${ }^{1}$, Ramalingeswara Rao, S. ${ }^{1}$, Naga Lakshmi, K. ${ }^{1}$, Latha. P. ${ }^{1,2}$ \& O. S. R. U. Bhanu \\ Kumar $^{1}$ \\ ${ }^{1}$ Department of Meteorology and Oceanography, College of Science and Technology, Andhra University, \\ Visakhapatnam, India \\ ${ }^{2}$ Dr. V.S. Krishna Government Degree College, Visakhapatnam, India \\ Correspondence: P. Sunitha, Dept. of Meteorology and Oceanography, Andhra University, Visakhapatnam 530003, \\ India. E-mail: sunitha.pmet@gmail.com
}

Received: July 13, 2018

doi:10.5539/mas.v12n9p221
Accepted: July 19, 2018

Online Published: August 27, 2018

URL: https://doi.org/10.5539/mas.v12n9p221

\begin{abstract}
The present study mainly focuses on heat and moisture budget components and its variations during meteorological drought conditions over India for the period, 1951-2013. The IITM sub-divisional summer monsoon standardised rainfall anomaly is considered to identify the meteorological drought, where the rainfall anomaly is less than one. From the analysis, thirteen meteorological droughts identified, and the rainfall decreased on spatial and temporal scales with significant changes in the frequency, duration and total amount of rainfall. In the lower levels, the westerlies are very weak where anti-cyclonic circulation is mainly observed along $60^{\circ}-70^{\circ} \mathrm{E}$. The intensity of easterly jet stream is decreased and further shifted towards south at $150 \mathrm{hPa}$ level in drought years. Next, anomalous variations in relative humidity and vertical velocity induce the maximum reduction in the moisture amount (15\%) in both lower and upper levels leads to weakening of local Hadley circulation strength. Next, the heat budget components are decreased over Bay of Bengal and coastal regions with a magnitude of 40 to $200 \mathrm{~W} / \mathrm{m}^{2}$ in drought years. It is observed that more moisture is transported to the equatorial region producing below average rainfall over the Indian subcontinent during weak monsoon periods. Hence, this study will help to identify the quantitative and qualitative estimation of drought conditions for long-range prediction of rainfall forecasting.
\end{abstract}

Keywords: meteorological droughts, latent heat flux, heat and moisture budget, hadley cell, summer monsoon.

\section{Introduction}

Indian agriculture and $70 \%$ of its population mainly depend on monsoon rainfall, which accounts for $25 \%$ of the GDP. The Indian summer monsoon is an integral part of the general circulation of the global earth-atmospheric systems. Large-scale circulation monsoon system forms every year over the Indian Ocean and its neighbouring areas during premonsoon and continues until the end of September. The tropical oceanic regions, in particular, the Arabian Sea, the Bay of Bengal, and the Indian Ocean are the primary reservoirs of heat and moisture of the monsoon. Monsoon early or delay onset in a few days can severely affect the economy, and also persistent droughts bring hazards on the enhanced productivity on agriculture.

The land-ocean thermal gradient plays a significant role in the monsoons (Mohanty et al., 1983; Pearce and Mohanty, 1984; Li and Yanai, 1996; Liu and Yanai, 2001). Studies on the relationship between tropospheric temperature in pre-monsoon and the Indian summer monsoon rainfall has been examined (Verma, 1982; Mooley and Paolino, 1988; Parthasarathy et al., 1990; Rajeevan et al., 1998; Kothawale and Rupa Kumar, 2002). Several investigations have been carried out to establish a possible relationship between sea surface temperature (SST), fluxes variations over the Indian seas and monsoon activity over the Indian subcontinent from different experiments (Pisharoty, 1965; Shukla, 1975; Weare, 1979; Das, 1983; Mohanty et al., 1983; Rao and Goswami, 1988; Mohanty and Mohan Kumar, 1990; Bhanu Kumar et al 2012, Roxy et al 2017, Suneetha et al., 2017). The flux transfer of heat and moisture from the ocean surface and the atmosphere exhibit significant variability over the Indian seas between the extreme categories of the monsoon flood and drought (Mohanty and Ramesh, 1993, Suneetha et al., 2018). Hastenrath and Lamb's (1980) study defines the importance of the cross-equatorial water vapour transport through the moisture budget of Southern Asia. Pisharoty (1965) and Peixoto and Oort(1983) suggest west coast of India received more moisture from the Arabian Sea from atmospheric water vapour budget. 
A few studies reported the role of moisture and heat budget during different phases of the Indian summer monsoon (Mohanty et al., 1983; Krishnamurti et al., 1988; Sengupta and Ravichandran, 2001; Hareesh Kumar and Mathew, 1997; Shenoi et al., 2002). The active/break conditions are responsible for possible occurence of flood and drought during this season.

According to India Meteorological Department (IMD), meteorological drought defined as deficient rainfall or a prolonged dry period with a shortage of soil moisture and rainfall relative to the extended period over an area. This type of drought is termed as one of the natural hazards which affects the millions of people (Blanford, 1884; Iyengar and Sudarshan 1982; Brooks et al., 2005). It is a recurrent condition of climate which effects decrease in soil moisture, groundwater, and flow in drains and streams. Year to year variation of droughts is unpredictable especially in a time of occurrence, duration, intensity, and extent of the area. Globally, number of drought indices are used in order to detect and monitor; Palmer drought severity index is one among widely used (Palmer 1965, Keyantash and Dracup 2002; Redmond 2002; Svoboda et al., 2002; Dai et al., 2004; Dai 2011; Verdin et al., 2005; Li et al., 2006). In recent times, drought planning and mitigation and other hazard assessment receive particular attention in climate change scenario (Byun and Wilhite 1999 Hayes et al., 2011). Hence identification of a precursor for flood/drought conditions has enormous importance for the meteorological community. So, studies relating to better understanding of the Indian summer monsoon droughts and their associated changes are very much importnant. Thus the objective of this study is to know the likely changes in the heat and moisture budget components over India during summer monsoon season, particularly in drought conditions.

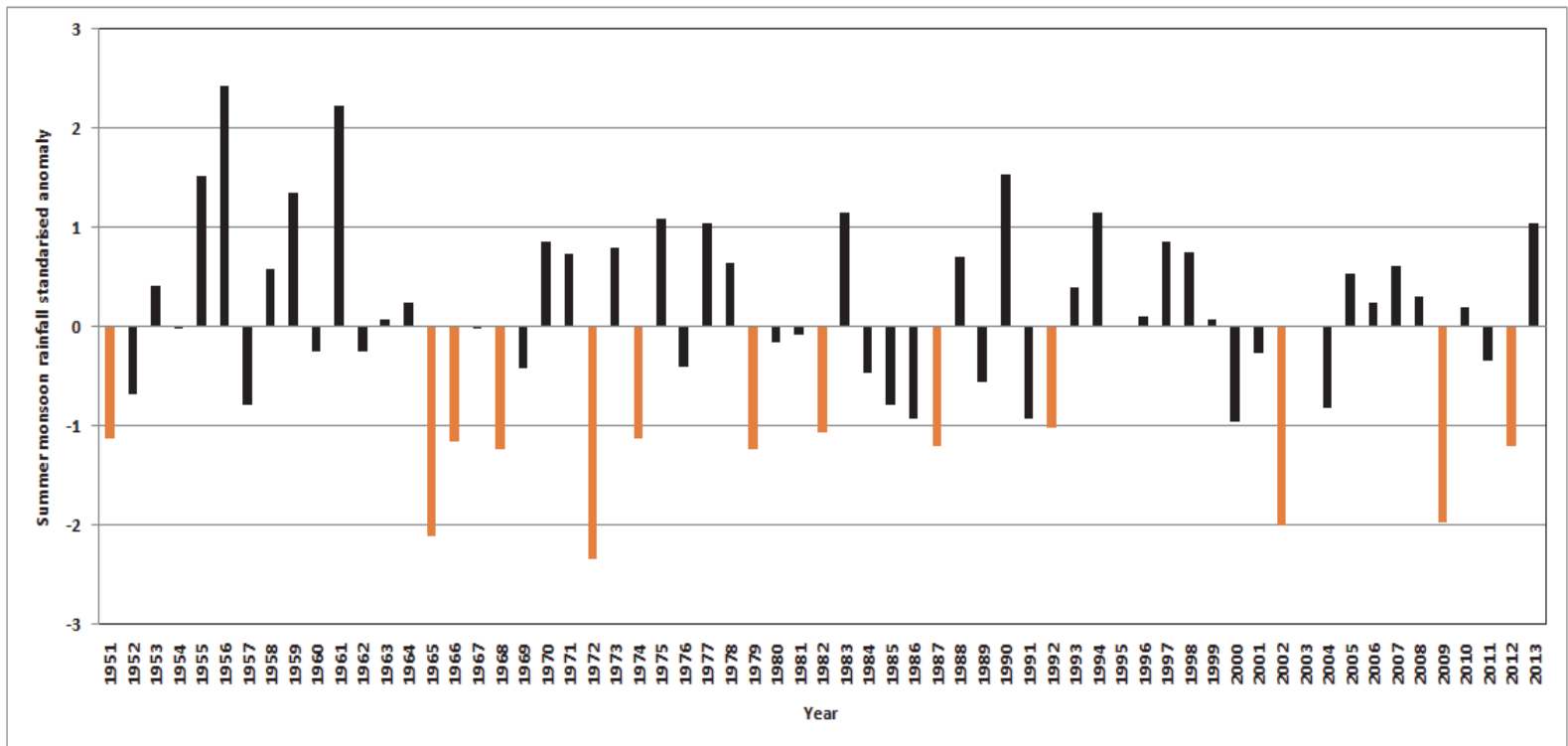

Figure 1. IITM sub-divisional year to year variation of summer monsoon rainfall for the period 1951-2013 (orange lines represented the meteorological drought years)

\section{Method}

The normal rainfall during southwest monsoon season is $890 \mathrm{~mm}$ for the country as a whole, and it is $611 \mathrm{~mm}$ in northwest India, $994 \mathrm{~mm}$ in central India, $723 \mathrm{~mm}$ in southern India and $1427 \mathrm{~mm}$ in northeast India. Out of 890 $\mathrm{mm}$ of normal rainfall in the country, June accounts for $162 \mathrm{~mm}$ followed by $293 \mathrm{~mm}$ in July, $262 \mathrm{~mm}$ in August and $175 \mathrm{~mm}$ in September. The IITM sub-divisional monthly rainfall values are obtained to identify meteorological droughts over India for the period 1951-2013. The meteorological droughts are considered where the rainfall anomaly less than one (Figure-1). From the analysis, thirteen meteorological droughts (1951, 1965, 1966, 1968, 1972, 1974, 1979, 1982, 1985, 1987, 2002, 2009 and 2012) are considered. Meteorological drought composites are prepared to identify the spatial distribution of rainfall with IMD gridded rainfall data. GISS surface airtemperature anomalies are obtained for understanding the land-sea thermal contrast during pre-monsoon season(March to May) for the study period. Later, Indian monsoon index data is obtained from the website http://apdrc.soest.hawaii.edu/projects/monsoon/ basing on the area $\left(40^{\circ} \mathrm{E}-80^{\circ} \mathrm{E}, 5^{\circ} \mathrm{N}-15^{\circ} \mathrm{N}\right.$ and $70^{\circ} \mathrm{E}-90^{\circ} \mathrm{E}, 20^{\circ} \mathrm{N}-$ $30^{\circ} \mathrm{N}$ ). This index is defined as the zonal wind difference between the two areas at the $850 \mathrm{hPa}$ level. Monthly values of heat budget and moisture budget components are computed mainly from NCEP/NCAR reanalysis data 
$\left(2.5^{\circ} \mathrm{X} 2.5^{\circ}\right)$ like specific humidity, air temperature, sensible heat flux, latent heat flux, ground heat flux, zonal and meridional components. The bulk equations are used for deriving latent and sensible heat fluxes to compute the heat budget.

\subsection{Heat Budget}

Heat budget components such as shortwave radiation flux (SWF), long-wave radiation flux (LWF), sensible heat flux (SHF), latent heat flux (LHF) and net heat flux (NHF) are used for climatology and also for drought years. The net heat budget equation $\left(\mathrm{W} \mathrm{m}^{-2}\right)$ can be written as

$$
\mathrm{Q}_{\mathrm{N}}=\mathrm{Q}_{\mathrm{R}}-\mathrm{Q}_{\mathrm{B}}-\mathrm{Q}_{\mathrm{H}}-\mathrm{Q}_{\mathrm{E}}
$$

Where $Q_{\mathrm{N}}$ is the NHF (W m ${ }^{-2}$ ), $Q_{\mathrm{R}}$ is the incoming $\mathrm{SWF}\left(\mathrm{W} \mathrm{m}^{-2}\right.$ ) (SWF), $Q_{\mathrm{B}}$ is the effective OLR flux (W m ${ }^{-2}$ ) $(\mathrm{LWF}), Q_{\mathrm{H}}$ is the $\operatorname{SHF}\left(\mathrm{W} \mathrm{m}^{-2}\right)$, and $Q_{\mathrm{E}}$ is the $\operatorname{LHF}\left(\mathrm{W} \mathrm{m}^{-2}\right)$.

\subsection{Moisture Budget}

This study uses the moisture budget equation described by Yanai et al. (1973). This equation states that the local variation of the precipitable water $(\mathrm{W})$ in the atmosphere can be written as

$$
\frac{\partial w}{\partial t}=-\nabla \cdot F+E-P
$$

where

$$
\mathrm{W}=\frac{1}{g} \int_{p t}^{p 0} q d p
$$

moreover, $F=F_{\lambda} i+F_{\varphi} j$ is the vertically integrated moisture flux in an atmospheric column. The zonal and meridional components are given as

$$
\begin{aligned}
& \mathrm{F}_{\lambda}=\frac{1}{g} \int_{p t}^{p 0} q u d p \\
& \mathrm{~F}_{\varphi}=\frac{1}{g} \int_{p t}^{p 0} q v d p
\end{aligned}
$$

moreover, $\mathrm{pt}=300 \mathrm{hPa}, \mathrm{p} 0=1000 \mathrm{hPa}$, and $\mathrm{g}$ is the acceleration due to gravity. Equation (1) states that the changes of total perceptible water in an atmospheric column are equal to the difference between the evaporation $\mathrm{E}$ and the sum of precipitation $\mathrm{P}$ and the vertically integrated moisture flux divergence $\nabla \cdot \mathrm{F}$. For a long-term average, $\partial \mathrm{W} / \partial \mathrm{t}$ vanishes; Equation (1) then becomes $\mathrm{E}-\mathrm{P}=\nabla \cdot \mathrm{F}$. This Equation is valid for observation and numerical model simulations. However, for the sake of brevity, Dc is not discussed here.

$$
\nabla . F=E-P+D C
$$

This equation is adopted for our study from Veiga et al., 2005. Variation of the heat and moisture budget components are also computed for drought conditions. The analysis provides an insight into the mechanisms that involve in the evolution of monsoon be mainly dependent on the heat source and moisture sources regions like the Arabian Sea and Bay of Bengal.

\section{Results}

\subsection{Spatial Distribution of Rainfall During Meteorological Drought Years}

Spatial distribution of Indian summer monsoon rainfall for the different meteorological drought years is shown in Figure-2. The primary peak of rainfall is mainly observed over the Western Ghats and Northeast India due to orographic effect. The lowest rainfall is mainly observed in Northwest India $(42 \mathrm{~mm} /$ day). In the year 1951, there is a high amount of rainfall over Western Ghats region, moderate rainfall over Chhattisgarh and Madhya Pradesh. Very less amount of rainfall is observed over Rajasthan, Karnataka and TamilNadu regions. In 1965, maximum rainfall observed over the Western Ghats and Arunachal Pradesh. Very less amount of rainfall $(3 \mathrm{~mm} /$ day $)$ is observed over Northwest India (Rajasthan, Srinagar, Jammu and Kashmir regions). In the years, 1966, 1968, 1972 the amount of rainfall varies in between $24-30 \mathrm{~mm} /$ day, $27-22 \mathrm{~mm} /$ day and $21-24 \mathrm{~mm} /$ day over Northeast region respectively. Next, the rainfall decreased in remaining meteorological drought years $(1974,1979,1982,1985,1987$ and 2002) compare to normal years. The average rainfall varies in between $21-35 \mathrm{~mm} /$ day over the Indian region during drought years. From this composites, it is evident that maximum amount of rainfall can be observed over 
Western Ghats and Northeast part of India. Next, very less amount of rainfall identified over Northwest and Southeast India. Hence this study revealed and there is a significant difference in between year to year on spatial and temporal scales especially on daily and seasonal variability of rainfall during meteorological drought years.
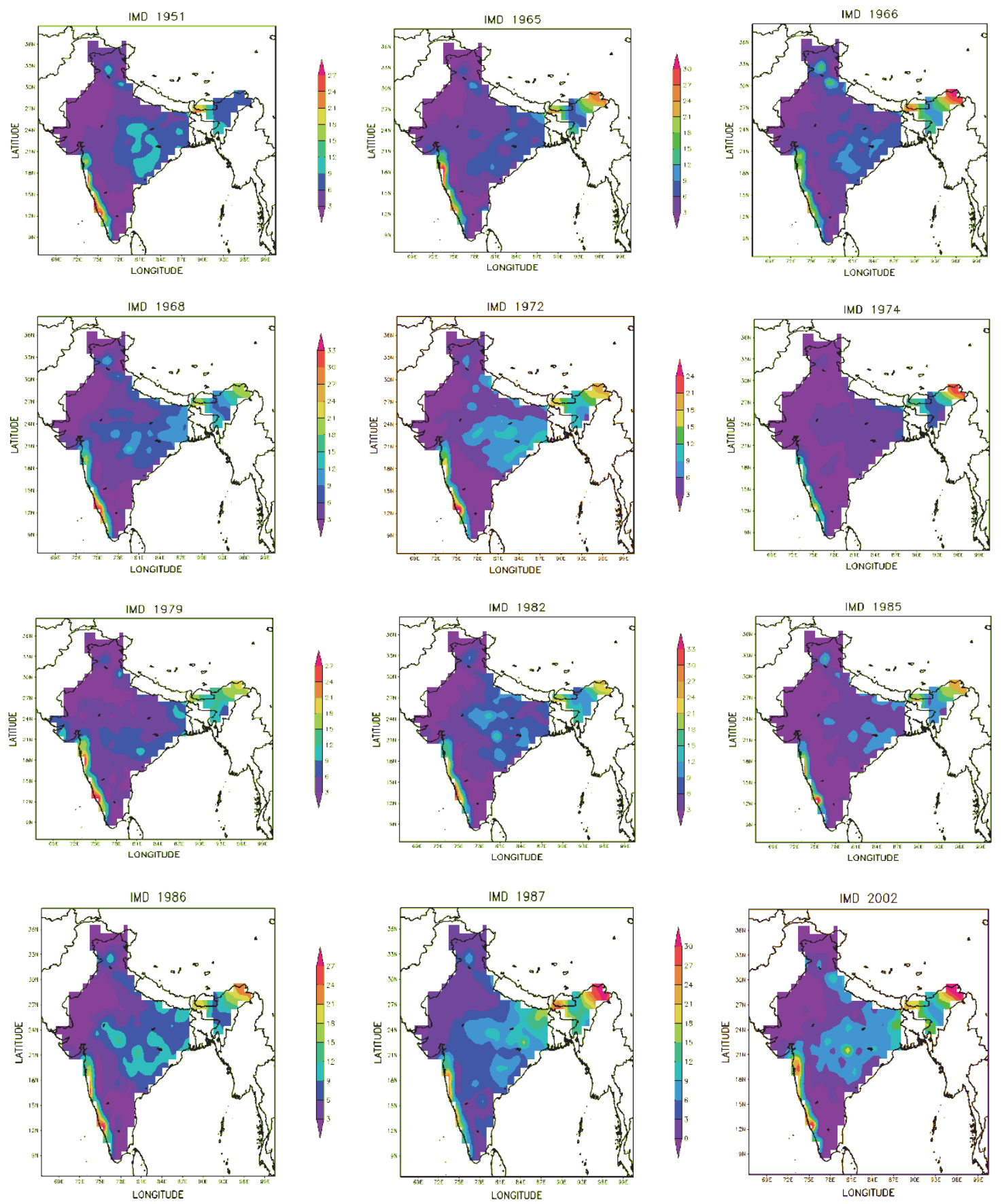

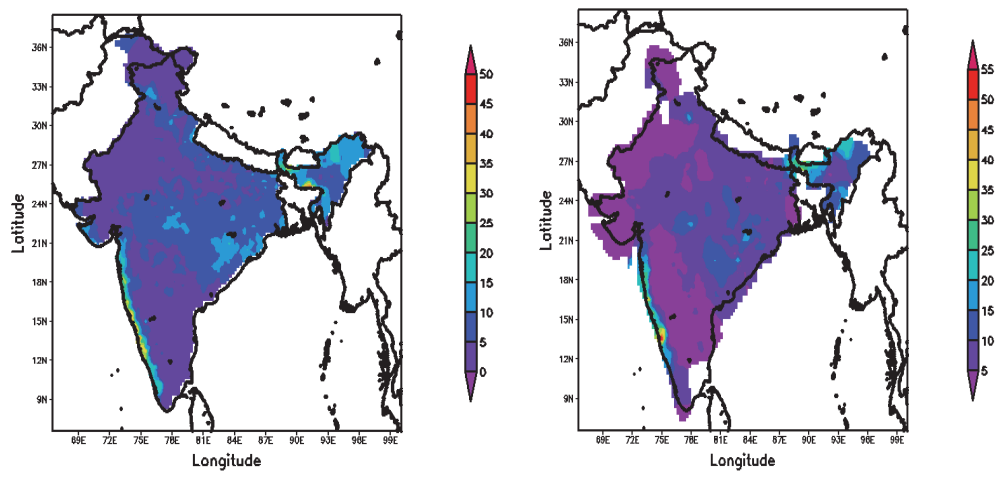

Figure 2. Spatial distribution of summer monsoon rainfall during thirteen meteorological drought years and climatology for the period 1951-2013

\subsection{Land-Sea Thermal Contrast}

Climatology infers surface temperatures are increasing over North Indian Ocean and decreasing over the land region, especially over northern India during the March through May. The Indo-Tibet high-pressure region also shows significant cooling $\left(0.3-0.05^{\circ} \mathrm{C}\right)$, while warming over the northwest region (Figure-3a). Next, the surface temperatures are decreasing mainly over the northwest region $\left(0.1^{\circ} \mathrm{C}\right.$ to $\left.-0.1^{\circ} \mathrm{C}\right)$ and represented in figure- $3 \mathrm{~b}$. Anomalous surface temperatures show that there is a significant cooling $\left(-0.3^{\circ} \mathrm{C}\right)$ observed over the northwest region (Figure-3c). Generally in the summer season, warming over northwest India is one of precursor to the active monsoon season. Thus the above analysis indicates that the thermal gradient between land and ocean is decreasing which leads to weak monsoon circulation during meteorological drought years.

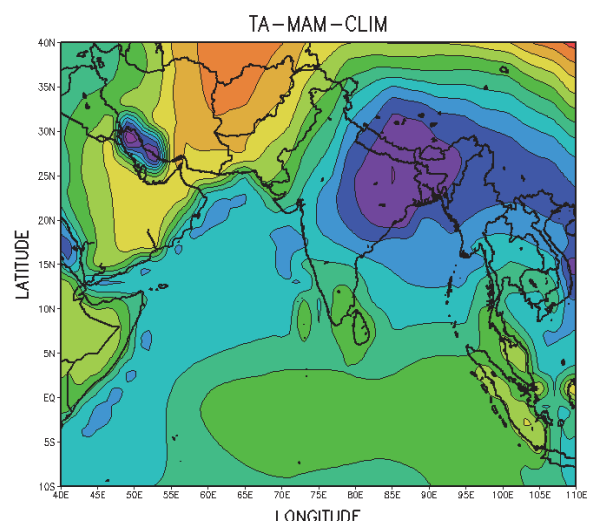

a) Climatology (summer)

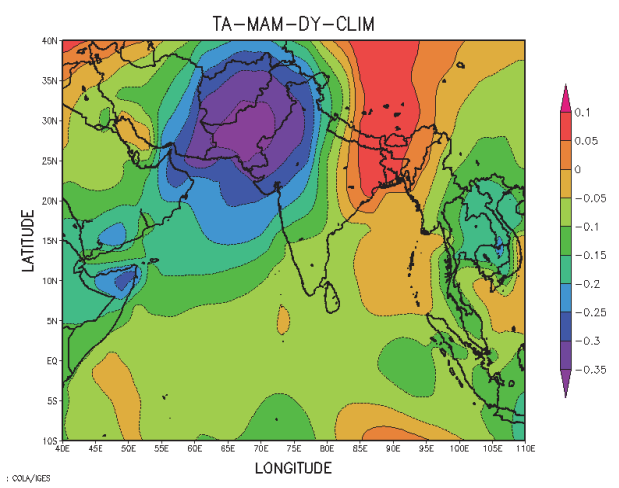

c) Anomaly

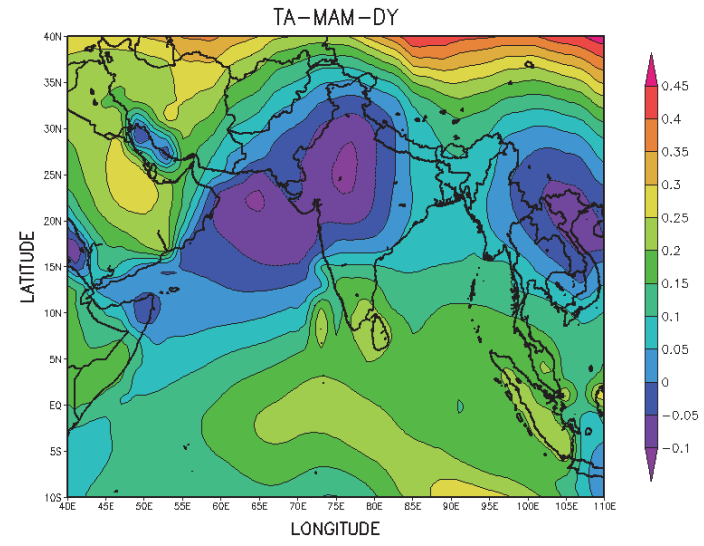

b) Drought years (summer)

Figure 3. GISS surface air temperature anomalies during a) climatology, b) during Meteorological droughts and c) anomalies from the meteorological droughts during summer season 


\subsection{Circulation Changes at 850 and $200 \mathrm{hPa}$ levels}

Strength and position of the Somali jet along the Africa Coast at $850 \mathrm{hPa}$ level and a tropical easterly jet stream along south India at $200 \mathrm{hPa}$ level are the essential features for active/break conditions of the monsoon season. Strong Somali jet carries moisture from the Arabian Sea to the west coast with strong low-level westerlies. Typically, this jet core extending from Africa to the Arabian Sea and it is very strong in summer monsoon season. Variations in the strength of the low-level jet have been linked to severe droughts and floods in the plains (Arritt et al., 1997; Mo et al., 1997). The potential impact of the low-level jet on precipitation is mainly observed during July through September (Weaver et al. 2009).

Figure-4a represents climatology, meteorological drought composites of low-level $(850 \mathrm{hPa})$ and upper-level circulation $(200 \mathrm{hPa})$ during summer monsoon season for the study period 1951-2013. The magnitude of low-level southwesterlies is very strong $(15.6 \mathrm{~m} / \mathrm{s})$ along the Africa Coast and over the Arabian Sea. The westerlies strength is reduced by $2.8 \mathrm{~m} / \mathrm{s}$ and maintained an anti-cyclonic circulation along $60^{\circ}-70^{\circ} \mathrm{E}$ during drought years (Figure$4 d$ ). At the upper level, the tropical easterly jet strength is also decreased in drought years when compared with the climatology (Figure-4.e). Thus the lower level southwesterlies and upper-level easterlies strength reduced during meteorological drought years.

\section{Climatology}

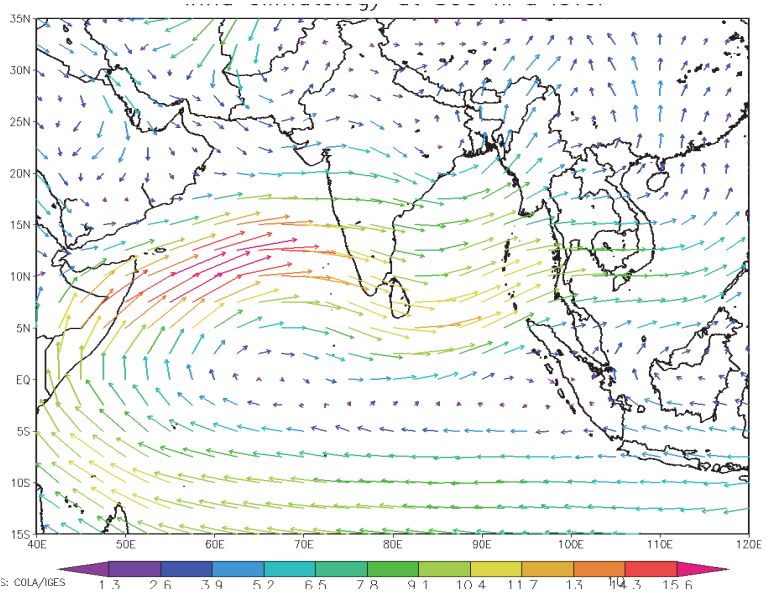

a) at $850 \mathrm{hPa}$

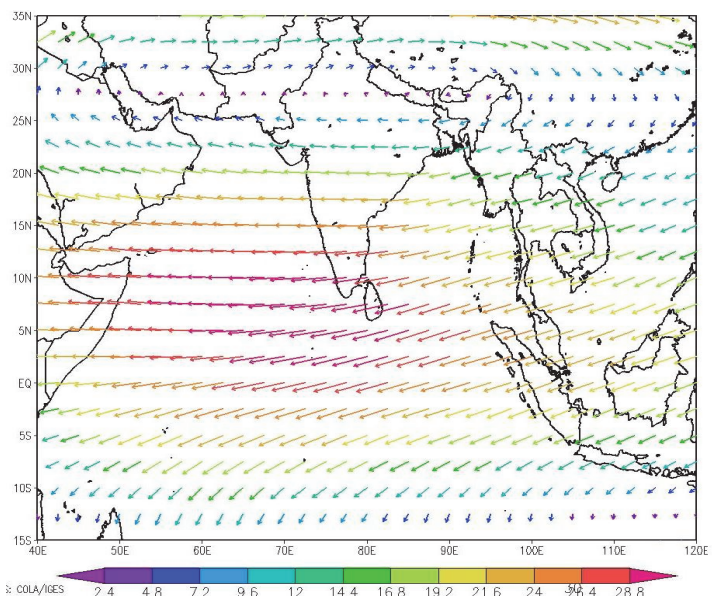

b) at $200 \mathrm{hPa}$

During drought years

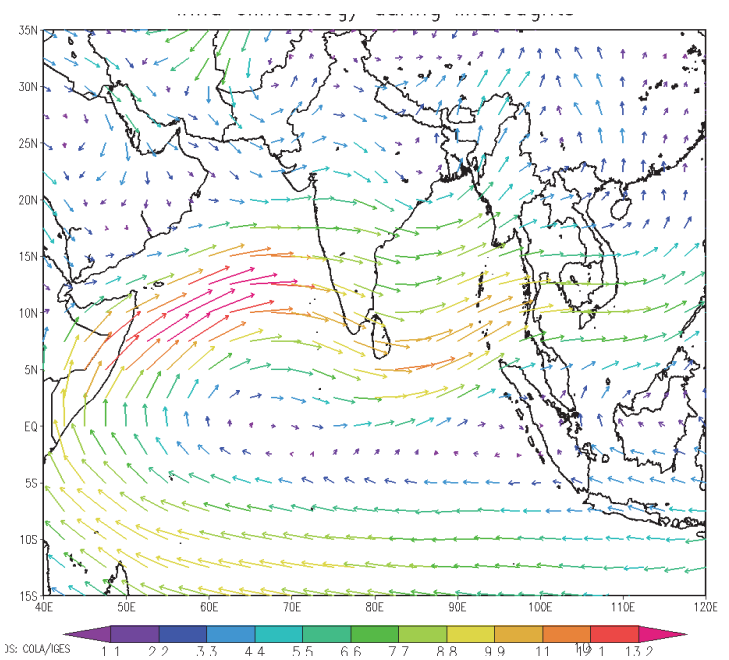

c) at $850 \mathrm{hPa}$

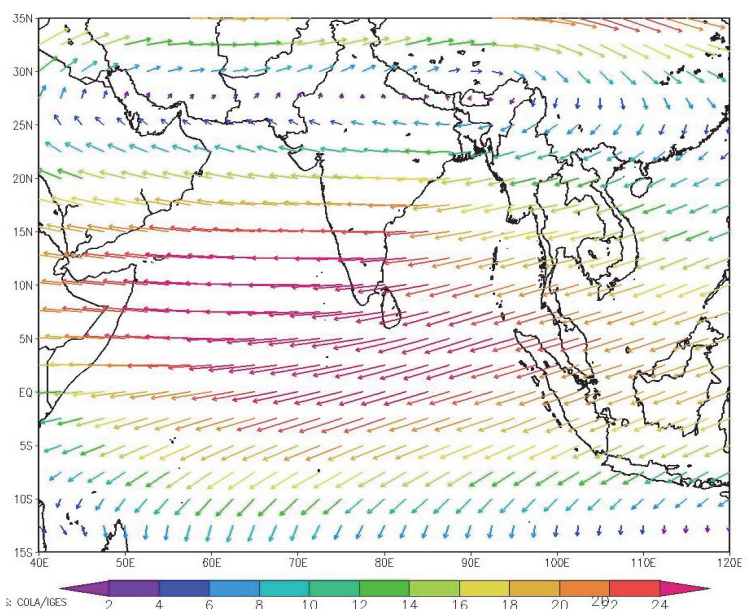

d) at $200 \mathrm{hPa}$

Anomalies 


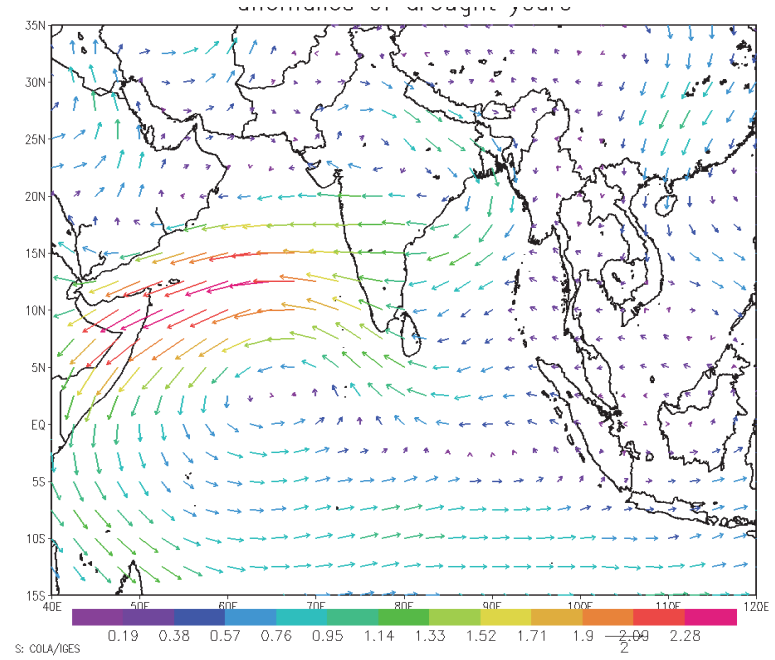

e) at $850 \mathrm{hPa}$

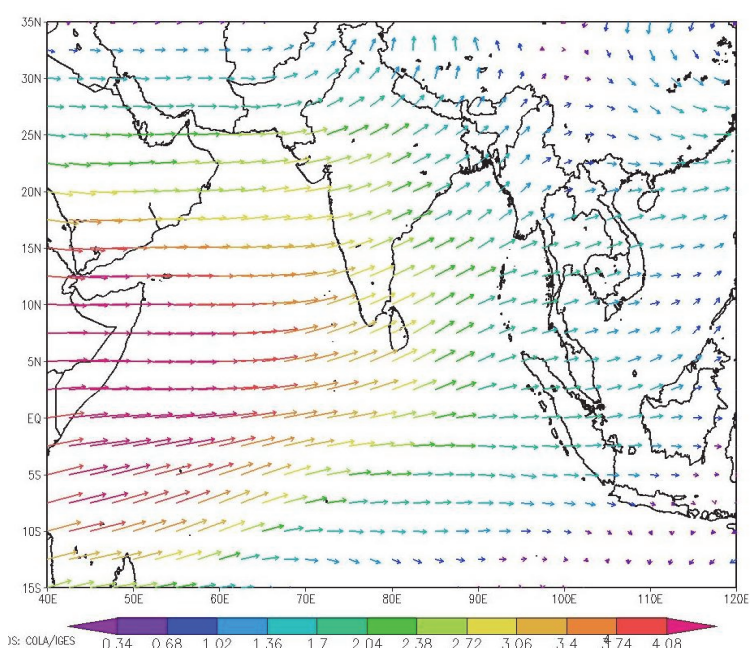

f) at $200 \mathrm{hPa}$

Figure 4. a, b,c,d,e and f. Circulation changes for climatology,drought years and their anomalies at 850 and $200 \mathrm{hPa}$ levels during summer monsoon period for the period 1951-2013

\subsection{Strength of Summer Monsoon.}

Indian monsoon index is obtained to analyze the strength of the monsoon for the period 1951-2013. This index varies in between -3 to 3 with different epochal behavior (Figure-5). The decreasing trend line is observed over the study region, and the equation is $\mathrm{Y}=-0.0147 \mathrm{X}+0.3083$ where ' $\mathrm{X}$ ' is the Indian monsoon index value. The root mean square error is 0.0836 .

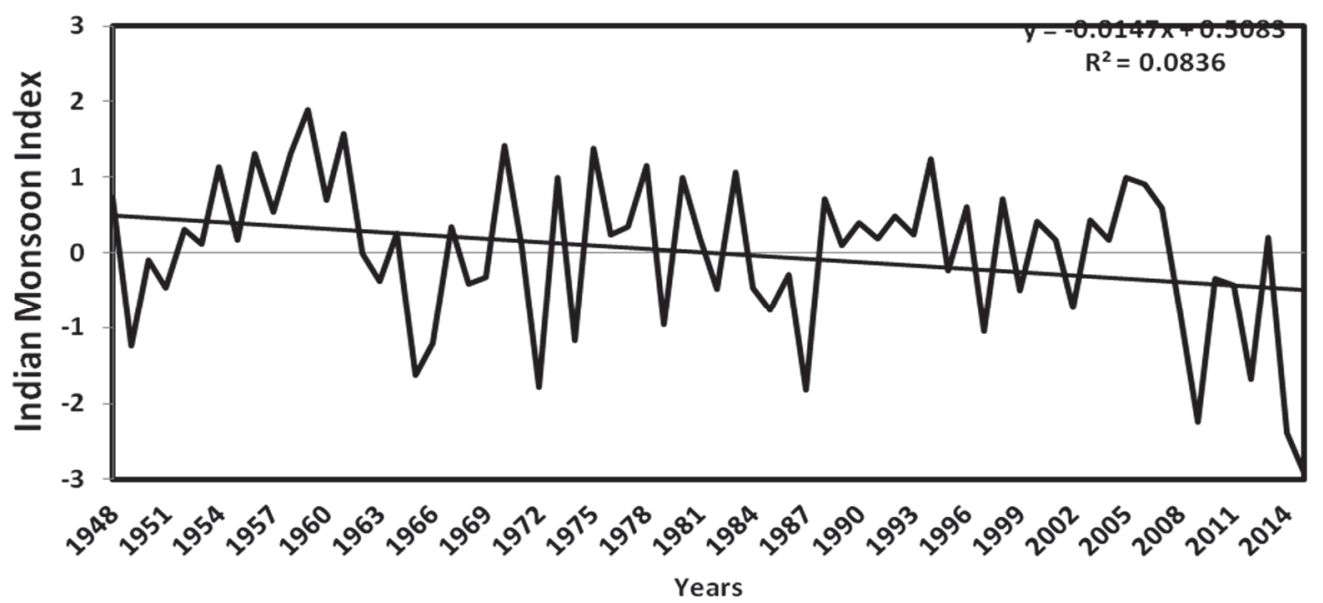

Figure 5. Indian monsoon index variation during summer monsoon season for the period 1948 to 2014

\subsection{Relative Humidity and Monsoon Hadley Circulation}

Tropical circulation is geared up to transport the excess heat to the higher latitudes, by atmosphere and ocean. Also, changes in strength and movement of Hadley circulation is essential for large-scale circulations that changes in surface winds, precipitation. A reverse Hadley cell with rising motion between $25^{\circ} \mathrm{N}-35^{\circ} \mathrm{N}$ and sinking motions over the south India, where upper limb is extending even up to $35^{\circ} \mathrm{N}$ (Oort and Rasmusson, 1971; Schulman, 1973 and Holton, 1992). The land-sea heating contrast of Indian sub-continent and the Indian Ocean and the latent heat release in the monsoon trough region sets up a vertical Hadley type circulation with southerlies in the lower levels and northerlies in the upper levels. Hadley cell circulation redistributes moisture to transport poleward which is a heat source for the atmosphere to higher latitudes; which reduces the tropical north-south temperature gradient (McGregor and Nieuwolt, 1998).

The saturation of the moisture content is reduced to $15 \%$ in the lower and upper level across south India during meteorological drought conditions (Figure-6a). Anomalous Hadley cell revealed that there is a reduction in sinking 
branch strength at upper levels in drought years (Figure-6b). The large-scale upward motion over the equatorial ocean while sinking motion mainly prevails over $20^{\circ} \mathrm{N}$ which induce the inhibition of convection. According to Roxy et al.,(2015) the warming of ocean enhances the local rainfall with high moisture which leads to a reduction in monsoon Hadley circulation.

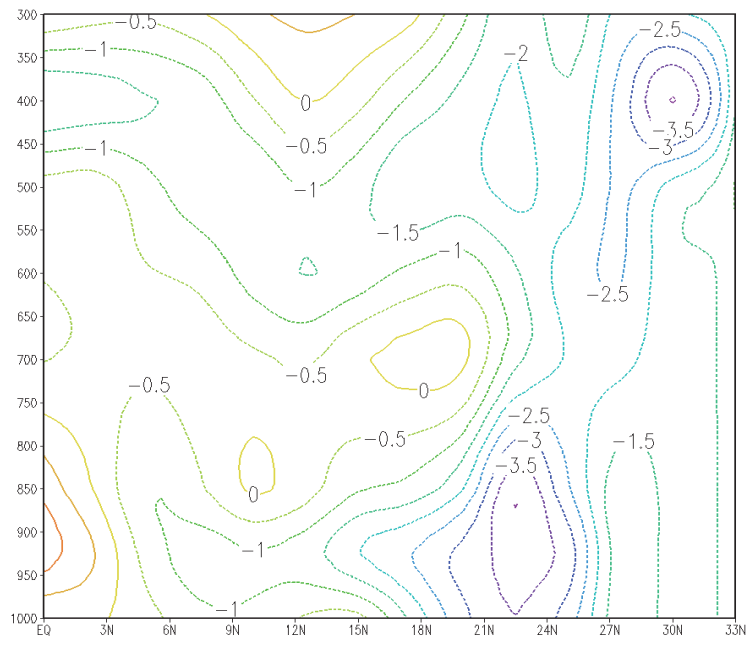

a) Relative Humidity

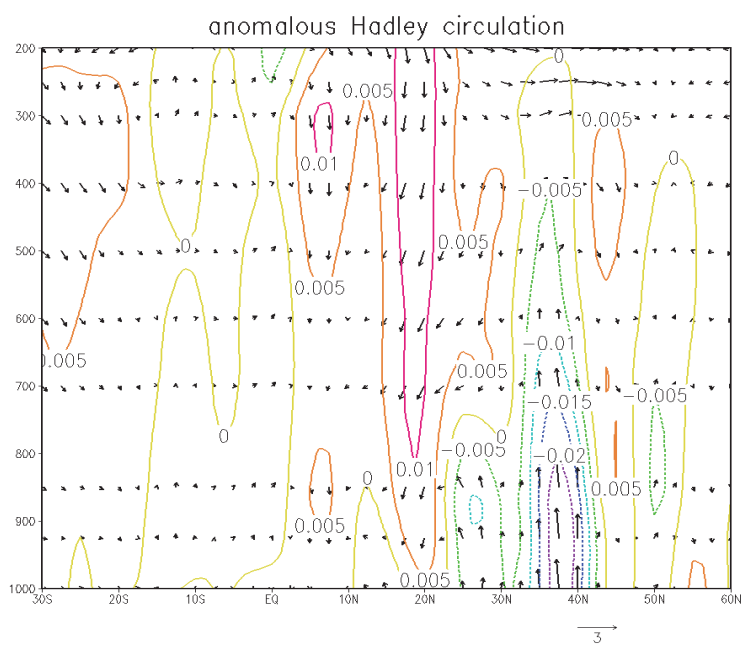

b) Monsoon Hadley circulation anomaly

Figure 6. Anomalous variation of a) Relative humidity and b) Hadley cell circulation during meteorological drought years

\subsection{Heat Budget Variations During Drought Years}

Monthly climatological variations of heat budget components are computed for summer monsoon months (Figure$7 \mathrm{a}, \mathrm{b}, \mathrm{c} \& \mathrm{~d})$. In June, the amount of heat flux $\left(180-240 \mathrm{~W} / \mathrm{m}^{2}\right)$ is mainly concentrated over the Somalia Coast and the Arabian Sea (Figure-7a). Next, the weak heat flux is prevailing over the Bay of Bengal than the Arabian Sea in July ( Figure-7b). Both cross equatorial flow and Somalia jet stream both play a significant role in establishing of the summer monsoon from the Arabian Sea to Indian peninsula in June and July. In August, the heat flux is increased $\left(>220 \mathrm{~W} / \mathrm{m}^{2}\right)$ over the Arabian Sea. Latent heat flux is more dominant over oceans than the sensible and ground heat flux. The Bay of Bengal branch shows increases in heat flux along off the coast of Sri Lanka. Generally, in August, the Bay of Bengal branch is very active due to the northwest propagation of monsoon depressions from the head Bay of Bengal (Figure-7c). Later the with drawl of prevailing westerliesover Indian region and heat flux reduced to $120-140 \mathrm{~W} / \mathrm{m}^{2}$ over the Bay of Bengal.

Figure- $8 \mathrm{a} \& \mathrm{~b}$ indicate that spatial distribution of net radiation (ground heat flux + latent heat flux + sensible heat flux) during Indian summer monsoon season for the study period. The magnitude of climatological heat flux varies in between 40 to $220 \mathrm{~W} / \mathrm{m}^{2}$ where the heat flux is high over southwest Bay of Bengal near $85^{\circ} \mathrm{E}$ with $220 \mathrm{~W} / \mathrm{m}^{2}$ (Figure-8a). Both the Bay of Bengal and the Arabian Sea are the two heat source regions for summer monsoon season. Among the two, Bay of Bengal is the active heat source compared with the Arabian Sea. The Arabian Sea heat flux is more connected with the cross-equatorial flow where the magnitude is very high along Somalia coast and over warm pool region $\left(>180 \mathrm{~W} / \mathrm{m}^{2}\right)$. Compare to climatological heat budget, the heat budget is fragile in magnitude of 40 to $200 \mathrm{~W} / \mathrm{m}^{2}$ during drought years(Figure- $8 \mathrm{~b}$ ). The prominent area is mainly observed over the Bay of Bengal especially off the coast of Sri Lanka and over the central Arabian Sea. 


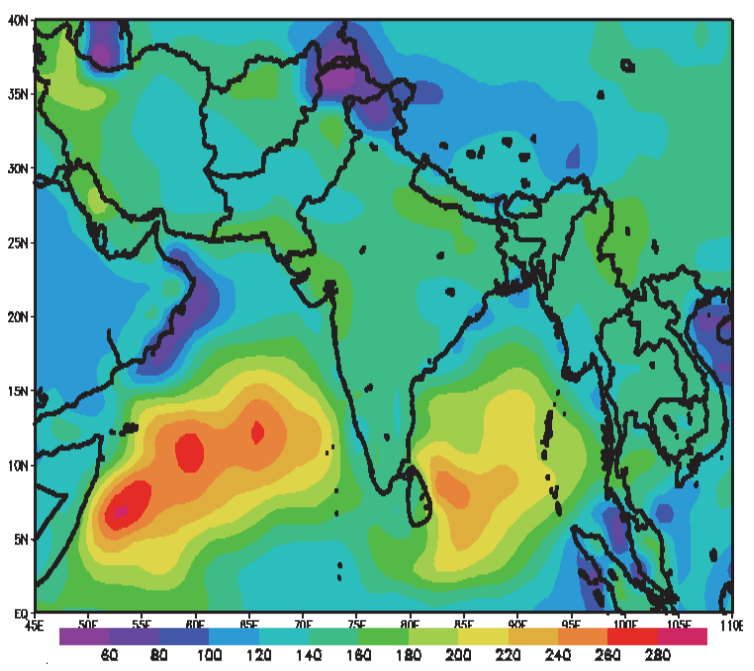

a) June

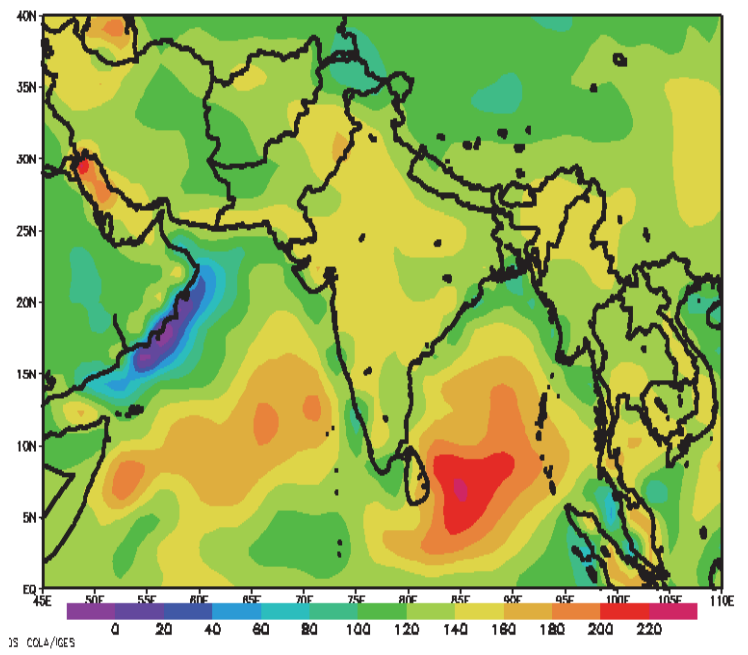

c) August

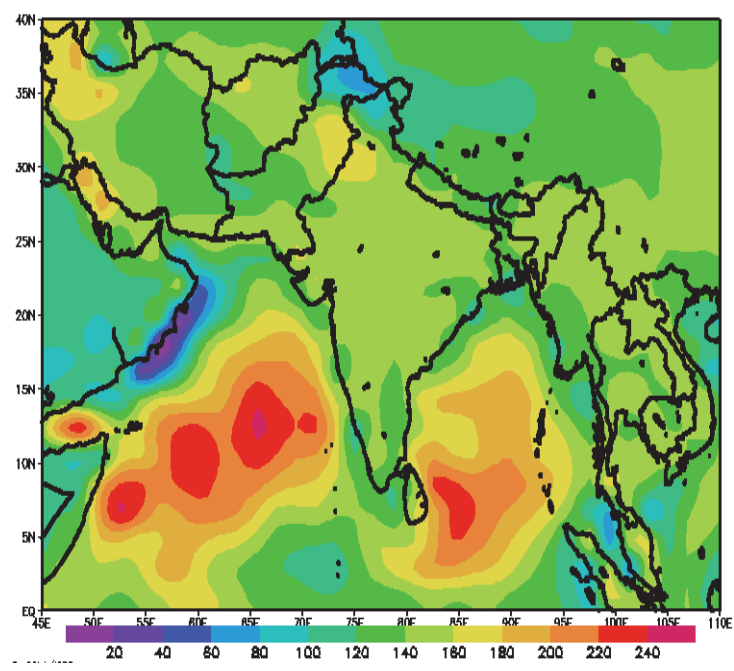

b) July

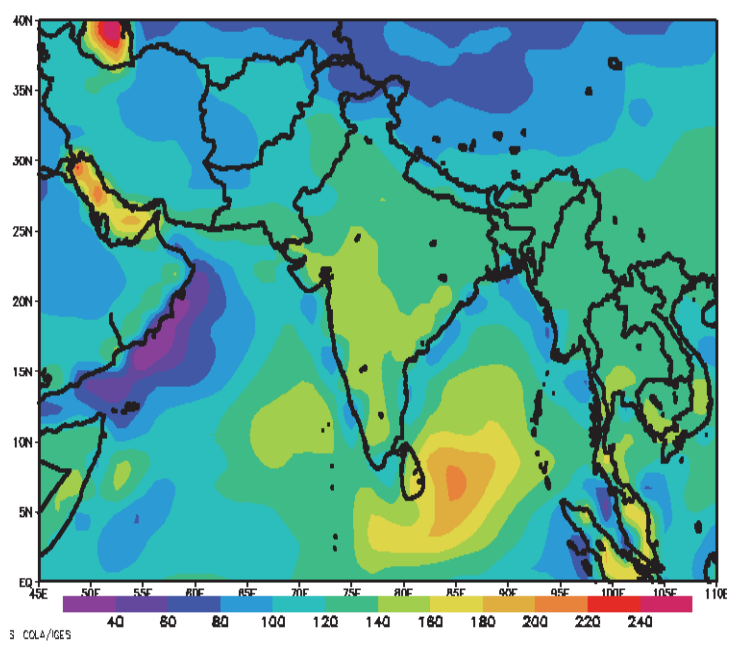

d) September

Figure 7. Climatological heat budget for the Indian summer monsoon season for the period (1951-2013) for a) June, b) July, c) August and d) September months.

\subsection{Sensible and Latent Heat Flux Variations During Drought Conditions}

Sensible heat provides the amount of energy transfer between the surface and air due to conduction and convection. From the figure-9a, the sensible heat flux anomaly is varied in between -18 to $12 \mathrm{~W} / \mathrm{m}^{2}$ during drought years. The highest amount of sensible heat flux is primarily observed over Coastal Andhra Pradesh $\left(12 \mathrm{~W} / \mathrm{m}^{2}\right)$ and Gujarat region. Thus the rate of evaporation is more due to biological activity, high temperatures over land. Figure-9b depicts the anomaly of latent heat flux $\left(-15\right.$ to $\left.15 \mathrm{~W} / \mathrm{m}^{2}\right)$ for drought years during the study period. Somalia coast, Coastal Andhra Pradesh and some parts of Gujarat and Maharashtra regions show a decrease in latent heat flux ($15 \mathrm{~W} / \mathrm{m}^{2}$ ). Andaman and Nicobar Islands and Myanmar coast are in the light of high latent heat flux. 


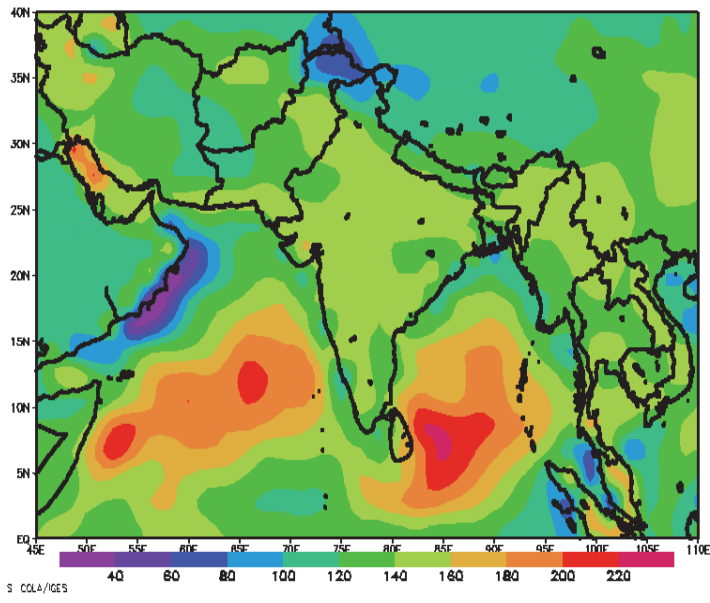

a) Climatology

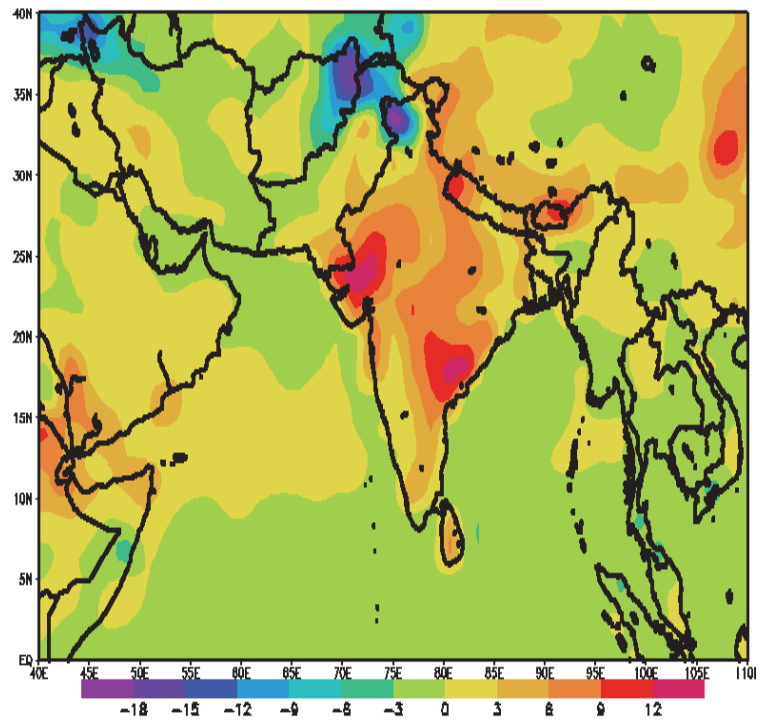

a)Sensible Heat Flux

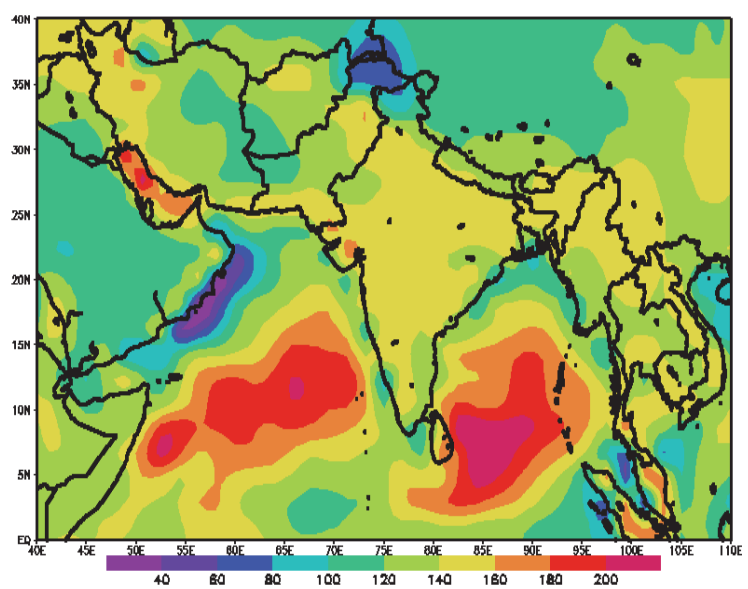

b) Drought years

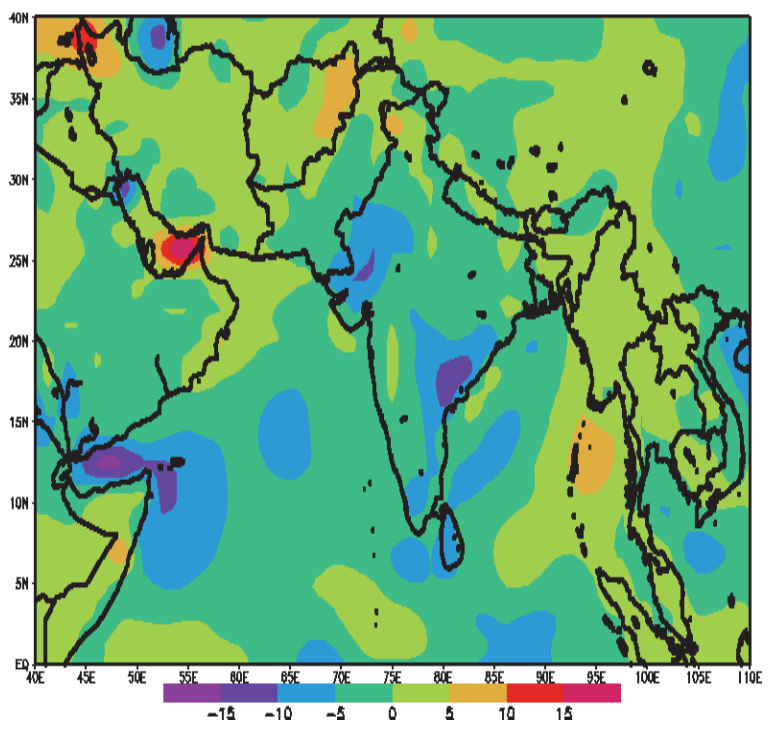

b) Latent Heat Flux

Figure $9 \mathrm{a} \& \mathrm{~b}$. Anomalous variation of sensible heat and latent heat for drought years during summer monsoon season for the period 1951-2013

The latent heat flux from ocean provides moisture for monsoon activity over Indian sub-continent. Figure-9b depicts the anomaly of latent heat flux $\left(-15\right.$ to $\left.15 \mathrm{~W} / \mathrm{m}^{2}\right)$ for drought years for the period 1951-2013. Somalia coast, Coastal Andhra Pradesh and some parts of Gujarat and Maharashtra regions show a decrease in latent heat flux ($15 \mathrm{~W} / \mathrm{m}^{2}$ ). Andaman and Nicobar Islands and Myanmar coast are in the shadow of high latent heat flux.

\subsection{Moisture Budget Variations During Drought Years}

Regional quantification of the hydro-climate process is mainly involved in heat and moisture transport from different source regions of the earth atmosphere and surface. The heat energy and moisture budgets are coupled together through processes like evaporation and condensation which contributes to the latent heat flux. Increases in heavy precipitation may not always lead to an increase in total precipitation over a season or over the year. The vertically integrated moisture flux divergence for the summer monsoon period is plotted for climatology and drought years in figure-10a \& b respectively. The amount of precipitation is more than the evaporation which is termed as a moisture sink. The significant moisture sink regions are mainly located in the Bay of Bengal, the Western Indian Peninsula with maximum rainfall regions. The regions of moisture source are located in the Arabian Sea, the coastal area of Africa and the southern Indian Ocean.

Figure-10a shows the vertically-integrated total moisture transport divergence for the summer monsoon season for the study period. Primarily, the northward transport of moisture is taking place from the southern hemisphere, 
crossing the equator to the Somali coast, Arabian Sea and Bay of Bengal through summer monsoon mean flow. The pattern of the moisture flux divergence is very similar to the patterns of rainfall and moisture source and sink. The most robust moisture convergence is located in the Bay of Bengal, Indian peninsula and northeast region. Simmonds et al., (1999) studied the moisture transport with ECMWF datasets. During drought conditions, the moisture transport is absent in the Bay of Bengal (figure-10b). The anomalous divergence is decreased (-1.5X10$6 / \mathrm{s}$ ) with less moisture transport into the Indian monsoon region and also the moisture source regions shifted from the original locations. During the break and weak monsoon conditions, more moisture is transported to the equatorial region producing below average rainfall over the Indian subcontinent.

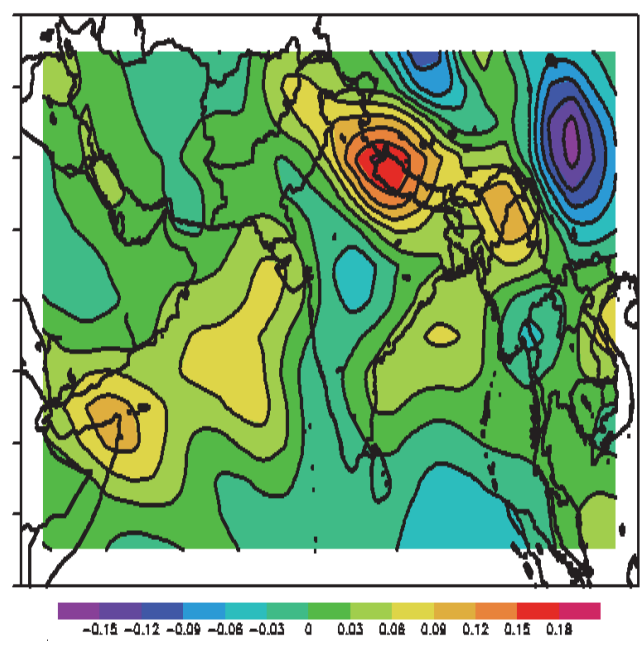

a) Climatology

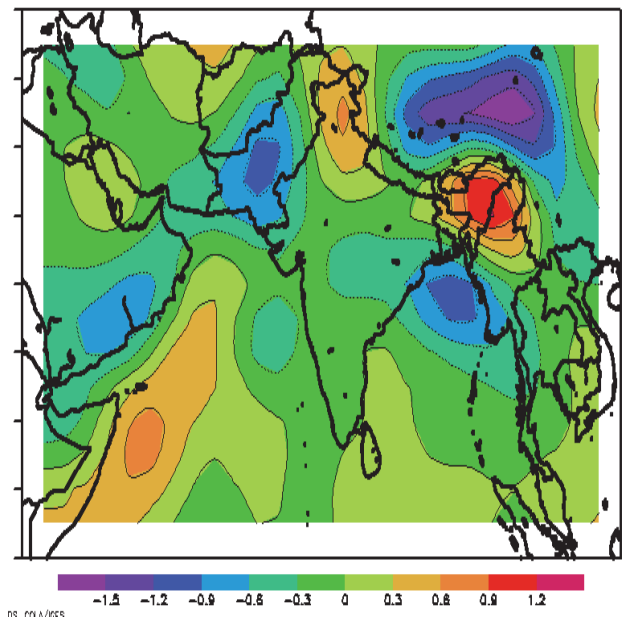

b) Drought years

Figure 10a\&b. Vertically integrated moisture flux divergence (X10-6/s) composites for climatology and drought years during Indian summer monsoon season for the period 1951-2013.

\section{Discussion}

Meteorological drought plays a vital role in India's economy and agricultural activities through insufficient soil moisture, shortage in water table over a particular region. Land-thermal contrast is decreasing due to the northsouth decreasing thermal gradient. India monsoon index is also decreasing in the recent years. Heat and moisture budgets of the climatology and drought years provide an insight of moisture source and sink regions of the summer monsoon season. During drought years, the Bay of Bengal moisture branch is very weak due to weak westerlies. The primary heat source regions are a southern hemisphere, Somalia coast, the Arabian Sea, and the Bay of Bengal. In the drought years, the sensible heat flux is high over land, while latent heat flux is very low over heat source regions. Anomalies of relative humidity, Hadley cell strength and movement, circulation at different levels also provide insight for a proper understanding of the prolonged dry conditions during drought years. Thus, this study helps in finding the meteorological drought conditions for the long and medium-range forecasting of rainfall.

\section{Acknowledgments}

The authors are thankful to DST-FIST and DST-INSPIRE program for providing infrastructural and financial support to carry out this research work. Also sincere thanks to the IMD, New Delhi, IITM, Pune and NCEP/NCAR research team for their Datasets.

\section{References}

Arritt, R. W., Rink, T. D., Segal, M., Todey, D. P., Clark, C. A., Mitchell, M. J., \& Labas, K. M. (1997). The Great Plains Low-Level Jet during the Warm Season of 1993. Mon. Wea. Rev, 125, 2176-2192.

Bhanu Kumar, O. S. R. U., Suneetha, P., \& Ramalingeswara Rao, S. (2012). Impact of rising sea surface temperatures on frequency of tropical storms and their relationships over north Indian Ocean. Can. J. Pure Appl. Sci., 5(3), 1675-1683.

Blanford, H. F.(1884). On the extension of the Himalaya snowfall with dry winds and seasons of drought in India. Proc. Roy. Soc. London, 37, 1-23.

Brooks, N., Adger, W. N., \& Kelly, P. M. (2005). The determinants of vulnerability and adaptive capacity at the national level and implications for adaption.Global Environ. Change, 15, 151-163. 
Byun, H., \& Wilhite, D. A. (1999). Objective Quantification of Drought Severity and Duration. J. Climate, 12, 2747-2756.

Dai, A. (2011). Characteristics and trends in various forms of the Palmer Drought Severity Index during 19002008. J. Geophys. Res., 116, D12115. https://doi.org/10.1029/2010JD015541.

Dai, A., Trenberth, K. E., \& Qian, T. (2004). A Global Dataset of Palmer Drought Severity AIndex for 1870-2002: Relationship with Soil Moisture and Effects of Surface Warming. J. Hydrometeor., 5, 1117-1130.

Das, P. K. (1983). IMO Monograph on Monsoons, Fifth IMO Lecture Series, World Meteorological Organization, Geneva, 155 pp.

Hareesh, K. P. V. \& Mathew, B. (1997). On the heat budget of the Arabian Sea. Meteorl. Atmos. Phys., 62(215), 215-224

Hastenrath, S., \& Lamb, P. J. (1980). On the Heat Budget of Hydrosphere and Atmosphere in the Indian Ocean. $J$. Phys. Oceanogr., 10, 694-708

Hayes, M. J., Svoboda, M. D., Wall, N., \& Widhalm, M. (2011). The Lincoln declaration on drought indices: universal meteorological drought index recommended. Bull. Amer. Meteorol. Soc., 92(4), 485-488.

Holton, J. R. (1992). An Introduction to Dynamic Meteorology (3rd ed). Academic Press, 511pp.

Iyengar S., Iyengar, S. S., \& Sudarshan P. (1982). A method of classifying regions from multivariate data Econ. Polit. Weekly, Special Article (1982), 2043-2052.

Keyantash, J. A., \& Dracup, J. A. (2002). The quantification of drought: An evaluation of drought indices. Bull. Amer. Meteor. Soc., 83, 1167-1180.

Kothawale, D. R., \& K. Rupa Kumar (2002). Tropospheric temperature variation over India and links with Indian summer monsoon: 1971-2000, Mausam, 53, 289-308.

Krishnamurti, T. N., Oosterhof, D. K., \& Mehta, A. V. (1988). Air-Sea Interaction on the Time Scale of 30 to 50 Days. J. Atmos. Sci., 45, 1304-1322.

Li, C., \& Yanai, M., (1996). The onset and interannual variability of the Asian summer monsoon in relation to land-sea thermal contrast. J. Climate, 9, 358-375.

Li, J., Gou, X., Cook, E. R., \& Chen, F. (2006). Tree-ring based drought reconstruction for the central Tien Shan area in northwest China, Geophys. Res. Lett., 33, L07715. https://doi.org/10.1029/2006GL025803.

Liu, X., \& Yanai, M. (2001). Relationship between the Indian monsoon rainfall and the tropospheric temperature over the Eurasian continent. Q.J.R. Meteorol. Soc., 127, 909-937.

McGregor, G. R., \& Nieuwolt, S. (1998). Tropical Climatology. John Wiley and Sons, Chichester.

Mo, K. C., Paegle, J. N., \& Higgins, R. W. (1997). Atmospheric Processes Associated with Summer Floods and Droughts in the Central United States. J. Climate, 10, 3028-3046.

Mohanty, U. C., \& Mohan, K. N. (1990). A study on energy fluxes in the surface boundary layer of the Indian seas during different epochs of the Asian summer monsoon Atmospheric Environment. Part A. General Topics, 24(4), 823-828.

Mohanty, U. C., \& Ramesh, K. J. (1993). Characteristics of certain surface meteorological parameters in relation to the interannual variability of Indian summer monsoon. Proc. Indian Acad. Sci. (Earth Planet Sci.) 102, 73. https://doi.org/10.1007/BF02839183

Mohanty, U. C. , Dube, S. K., \& Singh, M. P. (1983). A Study of Heat and Moisture Budget Over the Arabian Sea and Their Role in the Onset and Maintenance of Summer Monsoon. Journal of the Meteorological Society of Japan. Ser. II, 61(2), 208-221.

Mooley, D. A., \& Paolino, D. A. (1988). A predictive monsoon signal in the surface level thermal field over India. Mon. Weather Rev., 111, 339-352.

Oort, A. H., \& Rasmusson, E. M. (1971). Atmospheric Circulation Statistics. NOAA Prof. Paper No. 5, 323. (Available from U.S. Govt. Printing Office, Washington, D.C., 20402, stock No. 0317-00450.)

Palmer, W. C. (1965). Meteorological droughts. U.S. Department of Commerce, Weather Bureau Research Paper $45,58$.

Parthasarathy, B., Rupa Kumar, K., \& Sontakke, N. A. (1990). Surface and upper air temperatures over India in relation to monsoon rainfall. Theor Appl Climatol, 42(2), 93-110 https://doi.org/10.1007/BF00868216.

Pearce, R. P., \& Mohanty, U. C. (1984). Onsets of The Asian Summer Monsoon 1979-1982. J.Atmos.Sci., 41, $1620-1639$ 
Peixóto J. P., \& Oort A. H. (1983). The Atmospheric Branch Of The Hydrological Cycle And Climate. In StreetPerrott A., Beran M., \& Ratcliffe R. (Eds.), Variations in the Global Water Budget. Springer, Dordrecht.

Pisharoty, P. R. (1965). Evaporation from the Arabian Sea and the Indian Southwest Monsoon. Proc. Int. Indian Ocean Expedition, P. R. Pisharoty, Ed., 43-54.

Rajeevan, M., Pai, D. S., \& Thapliyal, V. (1998). Spatial and temporal relationships between global land surface air temperature anomalies and Indian summer monsoon rainfall. Meteorl. Atmos. Phys., 66(3-4), 157-171.

Rao, K. G., \& Goswami, B. N. (1988). Interannual Variations of Sea Surface Temperature over the Arabian Sea and the Indian Monsoon: A New Perspective. Mon. Wea. Rev., 116, 558-568. https://doi.org/10.1175/15200493(1988)116<0558:IVOSST>2.0.CO;2.

Redmond, K. T. (2002). The depiction of drought. Bull. Amer. Meteor. Soc., 83, 1143-1147.

Roxy, M. K., Subimal, G., Amey, P., Athulya, R., Milind, M., Raghu, M., Pascal, T., \& Rajeevan, M. (2017). A threefold rise in wide spread extreme rain events over central India - Nature Communications volume 8, Article number: 708.

Schulman, L. L. (1973). On the summer hemisphere Hadley cell. Q.J.R. Meteorol. Soc., 99, 197-201. https://doi.org/10.1002/qj.49709941916

Sengupta, D., \& Ravichandran, M. (2001). Oscillations of Bay of Bengal sea surface temperature during 1998 summer monsoon, Geophys. Res. Lett., 28, 2033-2036.

Shenoi, S. S. C., Shankar, D., \& Shetye, S. R. (2002). Differences in heat budgets of the near-surface Arabian Sea and Bay of Bengal: implications for the summer monsoon. J. Geophys Res., 107, 1-14.

Shukla, J. (1975). Effect of Arabian Sea-Surface Temperature Anomaly on Indian Summer Monsoon: A Numerical Experiment with the GFDL Model. J. Atmos. Sci., 32, 503-511,

Simmonds, I., \& Murray, R. J. (1999). Southern Extratropical Cyclone Behavior in ECMWF Analyses during the FROST Special Observing Periods. Wea. Forecasting, 14, 878-891

Suneetha, P., Lakshmi, K. N., Ramaligeswara, R. S., Zedek, D. M., \& Bhanu, K. O. S. R. U. (2018). Understanding the Role of Monsoon Depressions on Intraseasonal Oscillations over Indian Sub-Continent. International Journal of Geosciences, 9, 236-253. https://doi.org/10.4236/ijg.2018.94015.

Suneetha, P., Latha, P., Ramalingeswara, R. S., \& Bhanu Kumar, O. S. R. U. (2017). Influence of moisture source and sink regions on northeast monsoon rainfall. Met. Apps. https://doi.org/10.1002/met.1705.

Svoboda, M., \& Coauthors (2002). The drought monitor. Bull. Amer. Meteor. Soc., 83, 1181-1190.

Veiga, J. A., Rao, V. B., \& Franchito, S. H. (2005). Heat and moisture budgets of the Walker circulation and associated rainfall anomalies during El Niño events. Int. J. Climatol., 25, 193-213. https://doi.org/10.1002/joc. 1115

Verdin, J., Funk, C., Senay, G., \& Choularton, R. (2005). Climate science and famine early warning: Philosophical Transactions of the Royal Society B, v. 360, 2155-2168.

Verma, R. K. (1982). Long-range prediction of monsoon activity: A synoptic diagnostic study. Mausam, 33, 3544.

Weare, B. C. (1979). A Statistical Study of the Relationships between Ocean Surface Temperatures and the Indian Monsoon. J. Atmos. Sci., 36, 2279-2291.

Weaver, S. J., Schubert, S., \& Wang, H. (2009). Warm Season Variations in the Low-Level Circulation and Precipitation over the Central United States in Observations, AMIP Simulations, and Idealized SST Experiments. J. Climate, 22, 5401-5420.

Yanai, M., Esbensen, S., \& Chu, J. (1973). Determination of Bulk Properties of Tropical Cloud Clusters from Large-Scale Heat and Moisture Budgets. J. Atmos. Sci., 30, 611-627.

\section{Copyrights}

Copyright for this article is retained by the author(s), with first publication rights granted to the journal.

This is an open-access article distributed under the terms and conditions of the Creative Commons Attribution license (http://creativecommons.org/licenses/by/4.0/). 